\begin{tabular}{|l|l|l||}
\hline \multicolumn{2}{|c|}{ PublisherInfo } \\
\hline \hline PublisherName & $:$ & BioMed Central \\
\hline \hline PublisherLocation & $:$ & London \\
\hline \hline PublisherImprintName & $:$ & BioMed Central \\
\hline \hline
\end{tabular}

\title{
How old cells can regain youth
}

\begin{tabular}{|l|c|l||}
\hline \multicolumn{2}{|c|}{ ArticleInfo } \\
\hline \hline ArticleID & $:$ & 5062 \\
\hline \hline ArticleDOI & $:$ & $10.1186 /$ gb-spotlight-20050218-01 \\
\hline \hline ArticleCitationID & $:$ & spotlight-20050218-01 \\
\hline \hline ArticleSequenceNumber & $:$ & 38 \\
\hline \hline ArticleCategory & $:$ & Research news \\
\hline ArticleFirstPage & $:$ & 1 \\
\hline \hline ArticleLastPage & $:$ & 3 \\
\hline \hline & & RegistrationDate : 2005-2-18 \\
\hline ArticleHistory & $:$ & OnlineDate \\
\hline \hline ArticleCopyright & $:$ & BioMed Central Ltd2005-2-18 \\
\hline \hline ArticleGrants & $:$ & \\
\hline \hline ArticleContext & $:$ & 130596611 \\
\hline \hline
\end{tabular}


Old cells may regain a youthful phenotype when exposed to a young cell environment, say researchers in Nature this week. The results, say the authors, indicate that aged satellite cells have an intrinsic ability to regenerate.

"We know old tissue repairs poorly, but it's not because there aren't stem cells ready to do the repair," coauthor Thomas Rando told The Scientist. "The problem is, with age, the environment the stem cells hit changes, [and] it makes them less responsive."

To study how systemic factors affect satellite cell regeneration, researchers from Stanford University and VA Palo Alto Health Care System in California created fusions of the circulatory systems of old mice and young mice - a technique known as parabiosis. The young mice were transgenic, expressing either green florescent protein or a distinct CD45 allele.

Five days after injuring the mice's hindlimbs, researchers found nucleated embryonic myosin heavy chain, a specific marker seen in regenerating myotubes - nascent myofibers - in the old parabiotic animals. Because these cells did not contain transgenic markers, researchers determined that activation of resident progenitor cells - not engraftment of younger cells onto old tissue - was the cause of new growth.

Satellite cells in old parabiotic mice also showed similar upregulation as young mice controls of Notch ligand Delta, the binding protein necessary to activate the Notch signaling pathway for cell regeneration. The young parabiotic mice showed inhibition of Delta when compared with young mouse controls.

The new findings support the groups' previous work that showed the diminished expression of Delta related to age decreases Notch signaling, which reduces stem cell proliferation and impairs cell regeneration.

In the current study, researchers also found that culturing old satellite cells in young mouse serum restored upregulation of Notch ligand and Notch activation, whereas adding old mouse serum to young satellite cells inhibited the effect.

The results were a clear demonstration of how cell environment affects muscle regeneration, said University of Michigan professor of cell biology Bruce Carlson, who did not participate in the study. "It [shows] that muscle has a much greater potential to regenerate than you would think if you just looked at it in the context of the old animal," Carlson told The Scientist.

What Rando and colleagues found "argues against the idea that diminishing regenerative potency with age is a reflection of exhaustion of the stem cell population, and this gives great hope for restoring regenerative efficiency in aging individuals, since it is in principle easier to manipulate a systemic signaling system than to restore stem cells to diffuse tissues," Terence Partridge of Imperial College London wrote The Scientistin an E-mail. 
Looking for further evidence of rejuvenation in old cells, researchers also examined liver hepatocyte proliferation in parabiotic pairs. They found a two- to three-fold increase of such proliferation in cells taken from old mice. In vivo, formation of the cEBP alpha BRm complex - a growth aspect associated with proliferation inhibition in cells - was also diminished in old parabiotic mice.

In vivo and in vitro, the enhanced effect on old parabiotic mice cells was more dramatic than the inhibitory effect seen in the young cells. "There's a wrinkle, however," Rando said. When old and young cells were combined in young serum, the inhibitory factors predominated. "We don't know what the factors are [that control cell proliferation]... It may be as important, if not more important, to remove inhibitory factors from old serum than it is to add positive factors from young serum."

The researchers will continue work looking for individual factors that modify cell environment, factors that may regulate expression in Delta, and why it goes down with age. "Looking at age effects on muscle regeneration, there [are] probably at least four or five components... It's not just a one-variable phenomenon," noted Carlson.

\section{References}

1. I.M. Conboy et al., "Rejuvenation of aged progenitor cells by exposure to a young systemic environment," Nature, 433:760-4, February 17, 2005., [http://www.nature.com/nature]

2. D.M. Secko, "Notch-ing up muscle regeneration," The Scientist, November 28, 2003. [http://www.the-scientist.com/news/20031128/02]

3. Thomas A. Rando, [http://www.stanford.edu/group/neurology/fac/rando.html]

4. I.M. Conboy, T.A. Rando, "The regulation of Notch signaling controls satellite cell activation and cell fate determination in postnatal myogenesis," Dev Cell, 3:397-409, September 2002.

5. I.M. Conboy et al., "Notch-mediated restoration of regenerative potential to aged muscle," Science, 302:1575-7, November 28, 2003.

6. Bruce M. Carlson, [http://home.comcast.net/ carlson.james/]

7. Terence Partridge, [http://www1.imperial.ac.uk/medicine/people/terence.partridge.html] 